\title{
Pelatihan merancang Jumping Task melalui penerapan Lesson Study for Learning Community (LSLC) bagi guru-guru Bahasa Inggris di MTSN $1 \& 6$ Padang
}

\author{
Yenni Rozimela ${ }^{1}$, Desvalini Anwar ${ }^{2}$ \\ 12Universitas Negeri Padang... 12 \\ *)Corresponding author, Ð' yennirozi@gmail.com,desvalinianwar@yahoo.co.id
}

Revisi 20/06/2019; Diterima 23/07/2019;

Publish 08/08/2019

Kata kunci: Jumping Task, HOTS, LSLC, kolaborasi

\begin{abstract}
Abstrak
Kegiatan pelatihan merancang Jumping Task melalui penerapan Lesson Study for Learning Community (LSLC) bagi guru-guru Bahasa Inggris di MTSN 1 \& 6 Padang bertujuan untuk meningkatkan pemahaman dan keterampilan guru dalam mengintegrasikan aktivitasaktivitas belajar yang dapat mengasah keterampilan berpikir tingkat tinggi dan kritis siswa atau yang dikenal dengan istilah HOTS (High Order Thinking Skill). Jumping Task adalah sejenis tugas yang yang bersifat menantang yang dirancang guru agar siswa-siswanya dapat mengerahkan segenap usaha maksimalnya untuk menyelesaikannya. Tugas-tugas atau latihan-latihan berbasis Jumping Task mendorong siswa untuk tidak hanya berpikir kritis dan kreatif tetapi juga mengembangkan sikap dan nilai-nilai kerja sama atau kolaborasi. Lewat pemberian tugas Jumping Task yang dirancang guru diharapkan siswa menjadi terbiasa berkolaborasi dengan teman sejawatnya, saling berinteraksi dan mengembangkan sikap saling menghargai satu sama lainnya. Kegiatan pelatihan yang berlangsung selama lima kali pertemuan ini melibatkan dua orang dosen sebagai narasumber dan 15 orang guru Bahasa Inggris dari MTSN 1 \& MTSN 6 Padang. Pelatihan diisi dengan kegiatan memberikan Pre-Test, pemaparan materi, tanya jawab, merancang latihan-latihan Jumping Task, presentasi, memberikan Post-Test dan melakukan refleksi.
\end{abstract}




\section{Suluah Bendang: Jurnal Ilmiah Pengabdian Kepada Masyarakat}

\section{PENDAHULUAN}

\section{Analisis Situasi}

Di era revolusi industri 4.0 ini, tak terelakkan lagi teknologi telah menjadi bagian yang sangat penting dalam kehidupan manusia sehingga segala hal tampak dan terasa menjadi tanpa batas dan tidak terbatas akibat perkembangan massif internet dan teknologi digital di seluruh belahan dunia. Era ini menuntut lahirnya para generasi muda penerus bangsa yang memiliki tidak hanya kemampuan atau kecerdasan kognitif tetapi juga keterampilan atau kemampuan inovatif dan kreatif dimana keberadaan tehnologi dan media informasi yang tengah berkembang pesat seyogyanya dimanfaatkan untuk kebermanfaatan hidup manusia dan bukan sebaliknya untuk menghilangkan nilai-nilai kemanusiaan itu sendiri (Giroux,2010; Wahyuddin et al, 2017; Gates, Myhrvold \& Rinearson, 1996; Ormiston, 2011; Murti, 2015).

Ada beberapa jenis kemampuan yang harus dikembangkan oleh institusi pendidikan di era 4.0 ini. Kemampuan life skills misalnya akan melatih siswa mengenali dan memahami potensi dirinya dalam menjalankan tanggung jawab kehidupannya sehari-hari sebagai makhluk sosia. Sementara learning and innovation skills yakni kemampuan yang mendorong peserta didik agar bisa berpikir kreatif dan kritis dalam menyelesaikan masalah-masalah kompleks dalam kehidupannya dan mampu berkolaborasi serta berkomunikasi secara efektif dengan lingkungannya. Ketiga, yaitu literacy skills yakni kemampuan dan keterampilan individu dalam membaca dan memahami berbagai teks yang ada di sekitarnya baik yang tertulis maupun lisan.

Pentingnya kemampuan berpikir kritis dan kreatif juga dijabarkan dan ditegaskan dalam kurikulum nasional pendidikan Indonesia yang dikenal dengan istilah HOTS (High Order Thinking Skill) dalamKurikulum 2013. Berdasarkan perspektif Kurikulum 2013, peran guru sudah bergeser dari sumber belajar utama menjadi salah satu sumber belajar, dari pemberi tahu menjadi pemicu anak untuk mencari tahu serta dari "teacher dominated learning" menjadi fasilitator dan "learning observatory" (Manabu, 2014; Nofrion, 2017).

Fenomena pendidikan di Indonesia saat ini menunjukkan bahwa pengetahuan tentang penguatan HOTS sudah ada dan sudah mulai berkembang namun masih banyak kalangan pendidik yang kurang paham bagaimana cara menerapkan pembelajaran HOTS dalam PBM Bahasa Inggris. Cao (2018) menjelaskan bahwa pembelajaran berbasis HOTS tidak saja penting untuk mengasah pemikiran kritis siswa tetapi juga dapat memberikan kebermaknaan pembelajaran. Dari hasil wawancara informal dengan para guru dan kepala sekolah mitra, dapat disimpulkan bahwa sistem pendidikan Indonesia yang masih sangat berorientasi pada nilai dan keberhasilan siswa mengerjakan atau menjawab soal-soal ujian dengan baik menyebabkan hilangnya iklim belajar yang rileks, terbuka dan menyenangkan di ruang-ruang kelas sekolah mitra. Padahal dalam atmosfir belajar yang menyenangkan dan rileklah otak siswa akan merasa tenang dan berfungsi lebih baik untuk menghadapi atau mengerjakan persoalan-persolan yang menantang yang diberikan padanya. Sistem pendidikan yang masih berorientasi pada ujian tak pelak lagi pasti juga akan berpengaruh pada kebiasaan guru yang lebih banyak memberikan siswa latihan-latihan yang bersifat drilling dan menghapal (Sleeter, 2005; Snyder, L.G., \& Snyder, M. J. (2008).

\section{Solusi dan Target}

Berdasarkan temuan di lapangan bahwa guru masih memiliki pengetahuan dan keterampilan yang rendah dalam merancang tugas-tugas yang menantang yang mendorong siswa berpikir kritis dan kreatif serta adanya motivasi dan kesediaan guru dan kepala sekolah untuk bermitra, maka diputuskanlah untuk memberikan pelatihan merancang Jumping Task untuk penguatan HOTS melalui penerapan Lesson Study for Learning Community bagi guruguru Bahasa Inggris di MTSN 1 Lubuk Buaya danMTSN 6 Gunung Pangilun Padang.. Proposal 
yang sudah disetujui oleh LP2m UNP disahkan oleh LP2M yang kemudian mengeluar kontrak kerja. Kepala sekolah guru mitra menandatangani kesediaan bermitra di atas matrai. Dari pertemuan awal, disepakati Bersama-sama bahwa kKegiatan pelatihan berlangsung selama lima kali pertemuan tatap muka pada tanggal 30 Juli, 6, 20 dan 27 Agustus dan 10 September 2019. Lokasi kegiatan pelatihan bertempat di Universitas Negeri Padang.. Ditargetkan di akhir pelatihan, para guru sudah memiliki pengetahuan yang baik dalam merancang Jumping Task serta memiliki keyakinan, kemauan dan kemampuan untuk menerapkannya di sekolah mereka nanti. Diharapkan juga para guru bisa berbagi ilmu dan pengalaman dengan teman sejawatnya nanti.

\section{METODE PELAKSANAAN}

Secara garis besar pelatihan dibagi menjadi tiga tahap sesuai langkah-langkah yang ditawarkan oleh LSLC, yaitu perencanaan, pelaksanaan \& observasi dan refleksi. Pada tahap perencanaan dilakukan pengenalan dan peningkatan pemahaman guru terhadap konsep HOTS, Jumping Task, dan Lesson Study for Laerning Community (LSLC). Kegiatan pelatihan dimulai dengan memberikan Pre-Test pada guru-guru mitra untuk mengetahui pemahaman awal guru mengenai konsep-konsep dasar tentang Jumping Task, High Order Thinking Skill (HOTS) dan Lesson Study for Learning Community (LSLC). Selanjutnya guru mitra diberi pemahaman dasar tentang konsep-konsep yang ditanyakan dalam Pre-Test. Pemantapan dan pengenalan dilakukan dengan metode ceramah dan diskusi serta pemberian contoh dan kasus pada tahap 1 . Selanjutnya satu orang guru dipilih secara acak/sukarela untuk mempraktekkan Jumping Task yang sudah dirancang narasumber. Guru-guru lain dan pengabdi bertindak sebagai observer. Pada tahap kedua, guru diberi pelatihan tentang kiat-kiat merancang tugas atau latihan-latihan Jumping Task. Pada tahap ketiga, satu orang guru dari setiap kelompok diminta untuk menjadi guru model guna memperagakan praktek pemberian tugas Jumping Task sementara guru-guru mitra lainnya beserta narasumber melakukan observasi. Selanjutnya hasil observasi didiskusikan bersama-sama dalam kegiatan refleksi berupa masukan-masukan positif dari para guru mitra untuk penyempurnaan rancangan tugas Jumping Task yang telah dihasilkan selama kegiatan pelatihan berlangsung. Pada akhir pelatihan guru diberikan post-test untuk melihat kemajuan pemahaman dan keterampilan guru dalam merancang Jumping Task.

\section{HASIL DAN PEMBAHASAN}

Pelatihan yang berlangsung selama lima kali pertemuan tatap muka ini berlangsung sangat efektif dan teratur. Motivasi dan ketertarikan guru mitra untuk menerima dan mempraktekkan pengetahuan yang diperoleh dari narasumber terlihat jelas dari data kehadiran yang tinggi serta partisipasi aktif guru selama pelatihan berlangsung. Pengolahan hasil Pre-Test dan Post-test, partisipasi serta latihan-latohan yang dikerjakan guru mitra serlama pelatihan menunjukkan adanya peningkatan pemahaman guru terhadap konsep Jumping Task, LSLC, dan HOTS dan merancang Jumping Task untuk proses belajar mengajar Bahasa Inggris di MTSN.

\section{KESIMPULAN}

Kegiatan Pengabdian Masyarakat yang didukung oleh pendanaan dari PNBP LP2M Universitas Negeri Padang ini, dapat disimpulkan telah berhasil meningkatkan pengetahuan dan kemampuan guru mitra yang signifikan dalam merancang tugas-tugas Jumping Task. Kegiatan pelatihan ini diharapkan tidak berhenti sampai disini saja. Guru mitra diharapkan dapat menyebarluaskan pengetahuan dan keterampilannya pada rekan-rekan sejawatnya serta terus meningkatkan pengetahuan dirinya. Dengan meningkatnya kompetensi guru-guru bahasa Inggris di MTSN 1 dan MTSN 6 Padang diharapkan lambat laun akan meningkat pula kualitas pendidikan Bahasa Inggris di kota Padang khususnya dan Sumatera Barat pada umumnya. 


\section{DAFTAR PUSTAKA}

Cao, T. H. (2018). Teachers' Capacity of Instruction for Developing Higher-Order Thinking Skills for Upper Secondary Students-A Case Study in Teaching Mathematics in Vietnam. Revista Românească pentru Educaţie Multidimensională, 10(Suppl. 1), 8-19

Gates, B, Myhrvold, N \& Rinearson P. (1996). The Road Ahead. New York: Penguin Books, ISBN 978-0-14-026040-3.

Giroux, H.A, (2010).Dumbing Down Teachers: Rethinking the Crisis of Public Education and the Demise of the Social State, Review of Education, Pedagogy, and Cultural Studies, 32:4-5, 339-381.

Manabu, S (2014). Reformasi Sekolah Konsep dan Praktek Komunitas Belajar. Pelita-Jica Tokyo.

Murti, K. E. (2015). Pendidikan Abad 21 dan Aplikasinya dalam Pembelajaran di SMK

Nofrion, N. (2017). Peningkatan Aktivitas Belajar Siswa melalui Penerapan Metode Jumping Task pada pembejaran Geografi. Jurnal Geografi, 9(1), 11-20

Ormiston, Meg. (2011). Creating a Digital-Rich Classroom: Teaching \& Learning in a Web 2.0 World. New York: Solution Tree Press, ISBN 978-1-935249-87-0.

Sleeter, C. E. (2005) Un-standardizing curriculum: Multicultural teaching in the Standards-based classroom. New York, NY: Teachers College, Columbia University

Snyder, L.G., \& Snyder, M. J. (2008). Teaching critical 188 thinking \& problem solving skills. The DeltaPi Epsilon Journal, L(2), 90-9

Wahyudin, D., Rusman, R., \& Rahmawati, Y. (2017). Penguatan Life Skills dalam Implementasi Kurikulum 2013 pada SMA (Sekolah Menengah Atas) di Jawa Barat. Mimbar Pendidikan, 2(1) 